Proc. Estonian Acad. Sci. Biol. Ecol., 2001, 50, 4, 248-255

\title{
VERTICAL MIGRATIONS OF MYSIDS IN THE GULF OF RIGA
}

\author{
Ilmar KOTTA and Jonne KOTTA
}

Estonian Marine Institute, Marja 4d, 10617 Tallinn, Estonia; jonne@ sea.ee

Received 20 October 2000, in revised form 11 June 2001

\begin{abstract}
Vertical migrations of Mysis mixta, M. relicta, and Neomysis integer were studied in the north-eastern part of the Gulf of Riga during May-September 1999. All three mysid species performed diel vertical migrations. These migrations were more intense in late summer and autumn than in spring and early summer. The proportion of juveniles and small-sized adults $(<11 \mathrm{~mm})$ in the vertical migrations was higher than that of adults. Usually $N$. integer appeared in the water column first in the evening, followed later by Mysis spp. Both Mysis spp., often referred to as cold stenotherms, were found in high abundance in the surface waters in spite of very strong temperature gradients.
\end{abstract}

Key words: Baltic Sea, distribution, Mysidacea, Mysis, Neomysis.

\section{INTRODUCTION}

The literature on the vertical migration of mysids is not very extensive and mainly from fresh waters (e.g. Beeton \& Bowers, 1982; Lassenby et al., 1986). In the Baltic Sea the majority of studies have been focused on the mysid species inhabiting the open sea areas (Salemaa et al., 1986; Rudstam et al., 1989; Rudstam \& Hansson, 1990).

Shallow and eutrophicated bays are often characterized by much higher densities of mysids than similar open sea areas (Kotta \& Kotta, 1999). Hence, in these water bodies mysids are particularly important in the food webs (Kinne, 1955; Ojaveer, 1997). Owing to differences in depth, light regime, and temperature and salinity conditions it is likely that the diel changes in the vertical distribution of mysids in shallower seas differ considerably from those in deeper areas. 
This paper discusses the diel vertical migrations of mysids in the north-eastern part of the Gulf of Riga during May to September 1999. The distribution of the three most prevalent mysid species - Neomysis integer (Leach), Mysis mixta Lilljeborg, and $M$. relicta Lovén - is described. The first is confined to warmer waters while the two Mysis species are mainly found in colder waters. We also analyse whether temperature is limiting the vertical distribution of cold-water mysid species and whether there are differences in the structure of mysids length frequency between migrating and nonmigrating parts of the populations.

\section{MATERIAL AND METHODS}

Sampling was performed at a $25 \mathrm{~m}$ deep station in the north-eastern part of the

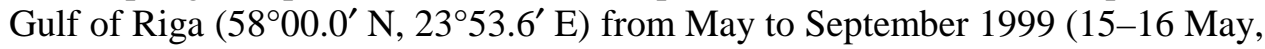
10-11 June, 17-18 Aug, 24-25 Sep). The Gulf of Riga is a relatively isolated water body. Its average salinity varies from $0.5-2$ PSU in surface layers in its southern areas to 7 PSU at the Irbe Strait. The northern part of the gulf is characterized by a wide coastal zone with a diverse bottom topography and extensive reaches of boulders. The gulf is on average twice as eutrophicated as the Baltic Proper (Mägi \& Lips, 1998).

The abundance of mysids in the near-bottom layer was estimated by a modified Rass dredge during daytime (Rass, 1933; Kotta \& Kotta, 1999). The abundance of mysids in the water column was obtained by vertical Hensen net (opening diameter $0.8 \mathrm{~m}$ ) tows, from $1 \mathrm{~m}$ off the bottom to surface. The mesh size of both nets was $0.4 \mathrm{~mm}$. The sampling was performed every hour (May, August) or every second hour (June, September) covering the period from sunset to sunrise (reported time is local summer time). In each sampling occasion three hauls were taken: from $5 \mathrm{~m}$ to surface, from thermocline to $5 \mathrm{~m}$, and from $1 \mathrm{~m}$ above bottom to thermocline. Earlier pilot studies (Kotta, 1980; Kotta, 1984) demonstrated that the within month variation in the vertical migration of mysids is moderate, hence, a period of one night is considered representative for the whole month. Temperature profiles were recorded during sampling.

All samples were stored in $4 \%$ buffered formaldehyde-seawater solution. Species composition, abundance, and biomass were determined in the laboratory. The total length (from rostrum to telson) of mysids was determined with a vernier caliper.

\section{RESULTS}

All three mysid species performed diel vertical migrations. The response to light was an important factor in the migrations. The migration began at sunset, usually reached a peak at 2:00 a.m. in May, June, and August and at midnight in September. A few individuals remained near the surface until dawn (Fig. 1). 

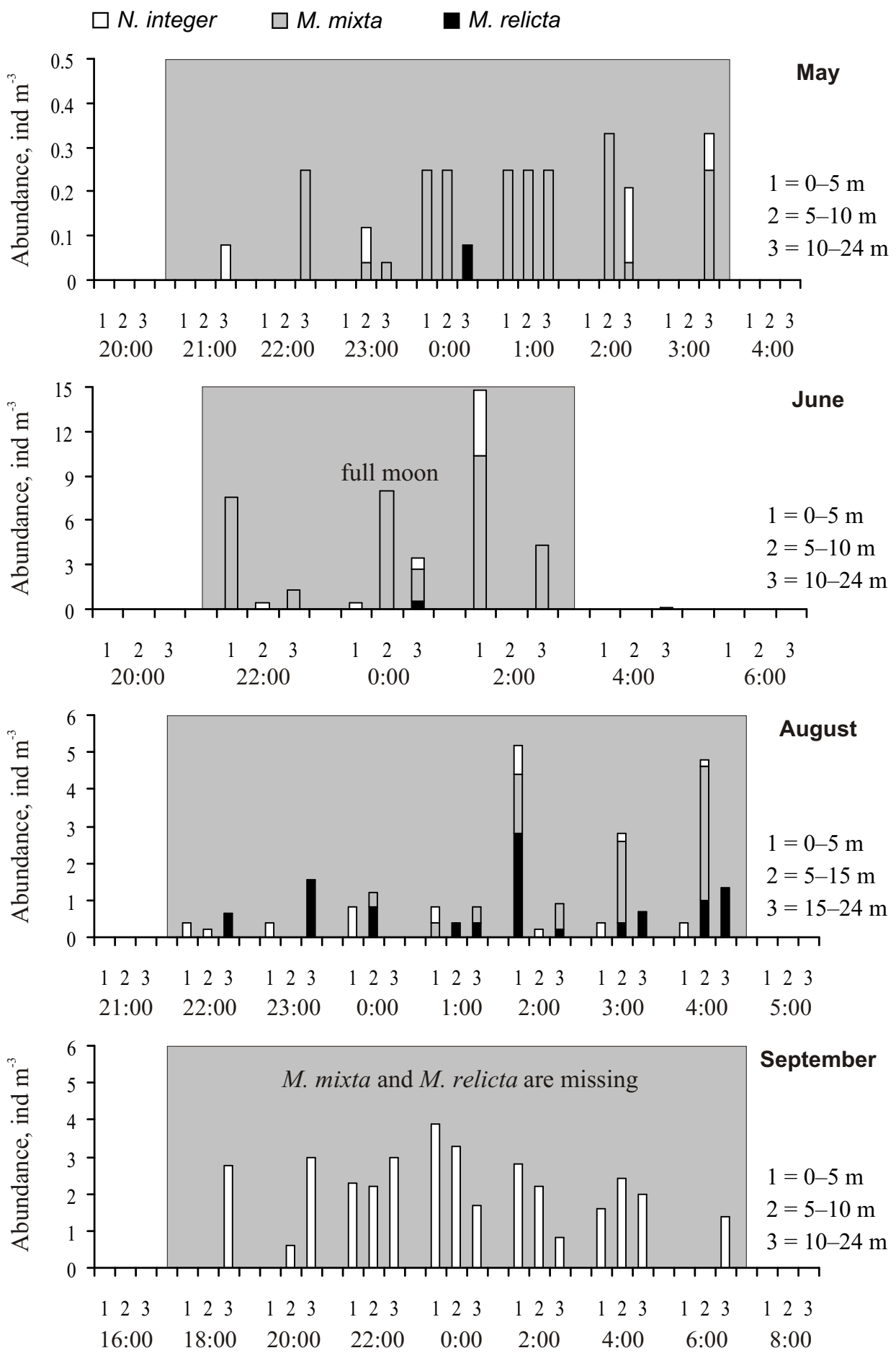

Fig. 1. Diurnal variation in the abundance of mysid species in the study area from May to September 1999. Periods between sunset and sunrise are indicated by grey. 
$N$. integer was relatively rare in the water column during May, June, and August. Higher abundances were recorded only during June at 2:00 a.m. On the other hand it was the only mysid species found in the study area during September and its abundances were many times higher than recorded earlier in the year.

M. mixta was observed at low abundances in the water column in May and was missing in September. The species dominated in the samples during June and its abundance was slightly lower in August. M. relicta was found in higher numbers during August. Occasionally, the share of M. relicta exceeded even that of M. mixta and N. integer. In May, June, and September the share of M. relicta was negligible.

Regardless of species the proportion of juveniles and small-sized adults $(<11 \mathrm{~mm})$ was higher in the vertical migrations than that of adults (Fig. 2). Just after sunset the small-sized mysids started to migrate towards surface layers. Usually $N$. integer was the first to appear to the water column, followed later by Mysis spp. The migration of adults was delayed about 3-4 hours. Hence, the importance of adults in the water column increased with the duration of dark period at night. In June strong moonlight had an effect on the pattern of the vertical distribution of mysids. By shortening the dark period it induced a very clear peak in the vertical migration of mysids. When clouds overshadowed the moon the maximum abundance values of mysids were recorded $\left(15\right.$ ind $\left.\mathrm{m}^{-3}\right)$.

The vertical distribution of mysids was not affected by the temperature conditions. Both $M$. mixta and M. relicta were found in the surface layer despite the occurrence of strong temperature gradients. Only in September the coldloving $M$. mixta and $M$. relicta were not observed in the study area when the temperatures of the near-bottom layer were too high for the species. Figure 3 illustrates the temperature profiles in the study area in different seasons.

\section{DISCUSSION}

The results of this study are in accordance with previous works demonstrating that the vertical migration of mysids is related to light levels. During upward migrations induced by low light mysids prey on phytoplankton and zooplankton while in daytime they feed mainly on detritus (Sanina, 1961; Chekhova, 1961; Rudstam et al., 1989). Vertical migrations of mysids in stratified waters allow them to save the energy for reproduction (food is less sparse in warmer waters, the consumption of energy is lower at lower temperatures) and better escape from predators (see e.g., MacLaren, 1974; Beeton \& Bowers, 1982).

The monthly differences in the diel vertical migration of mysids are partly explained by their seasonal pattern of reproduction. During May the population of $N$. integer consists mainly of a few overwintering individuals (Järvekülg, 1965), which do not perform such pronounced migrations as juveniles do (Sanina, 1961). 


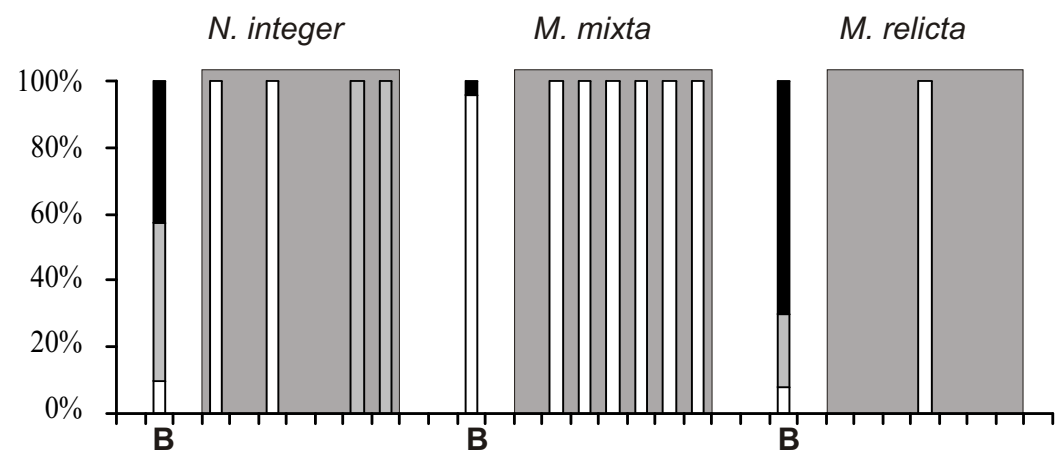

May

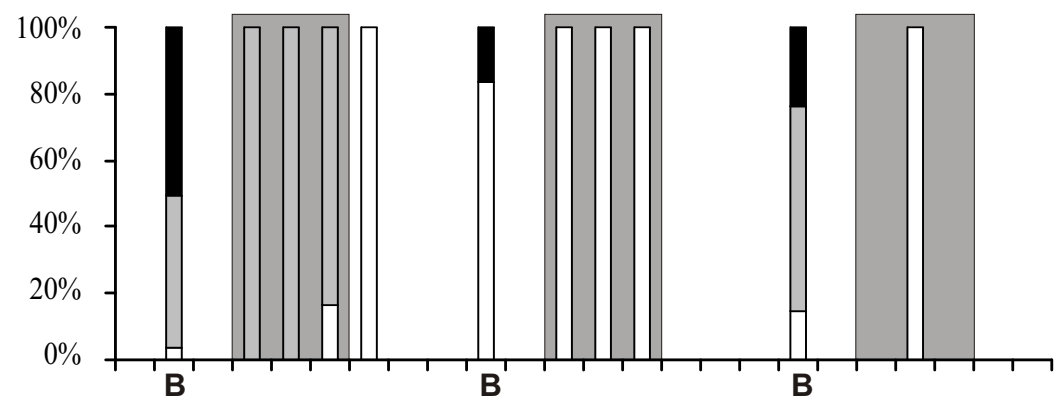

June

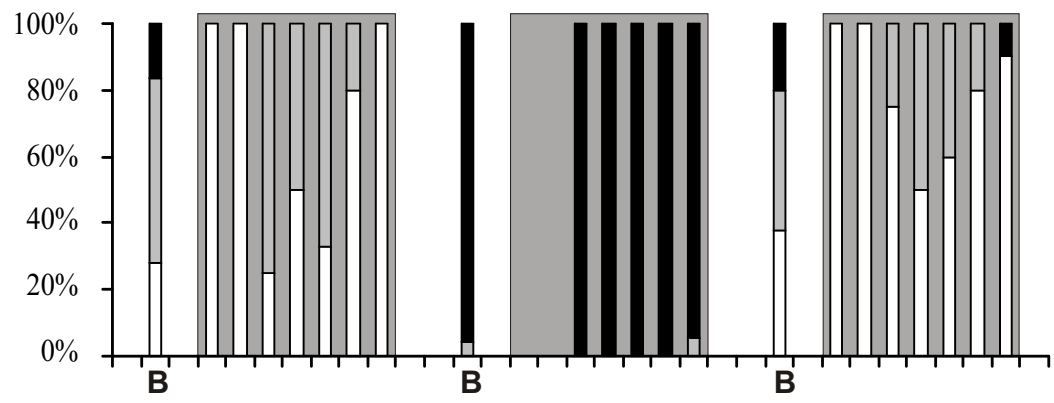

August

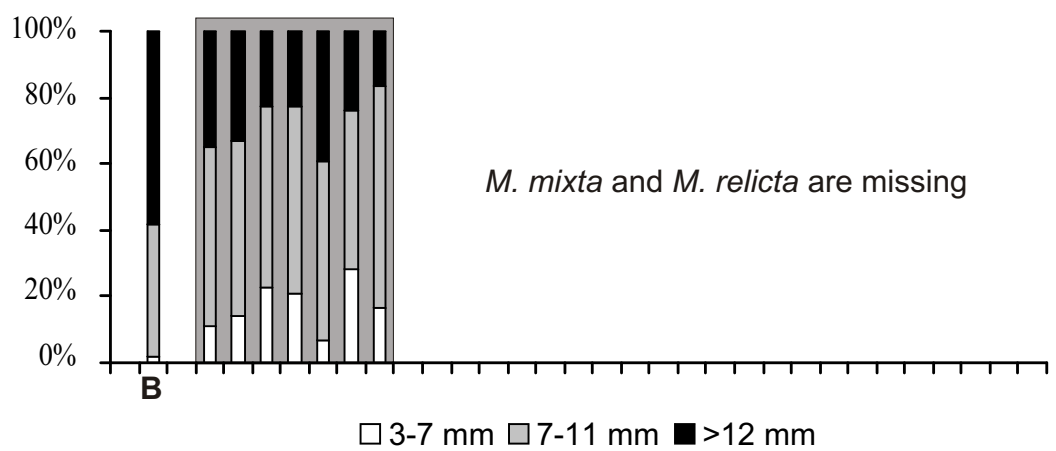

September

Fig. 2. Diurnal variation in the length structure of migrating populations of mysids in the study area from May to September 1999. Periods between sunset and sunrise are indicated by grey; B shows the population length structure of mysids at bottom during daytime. 


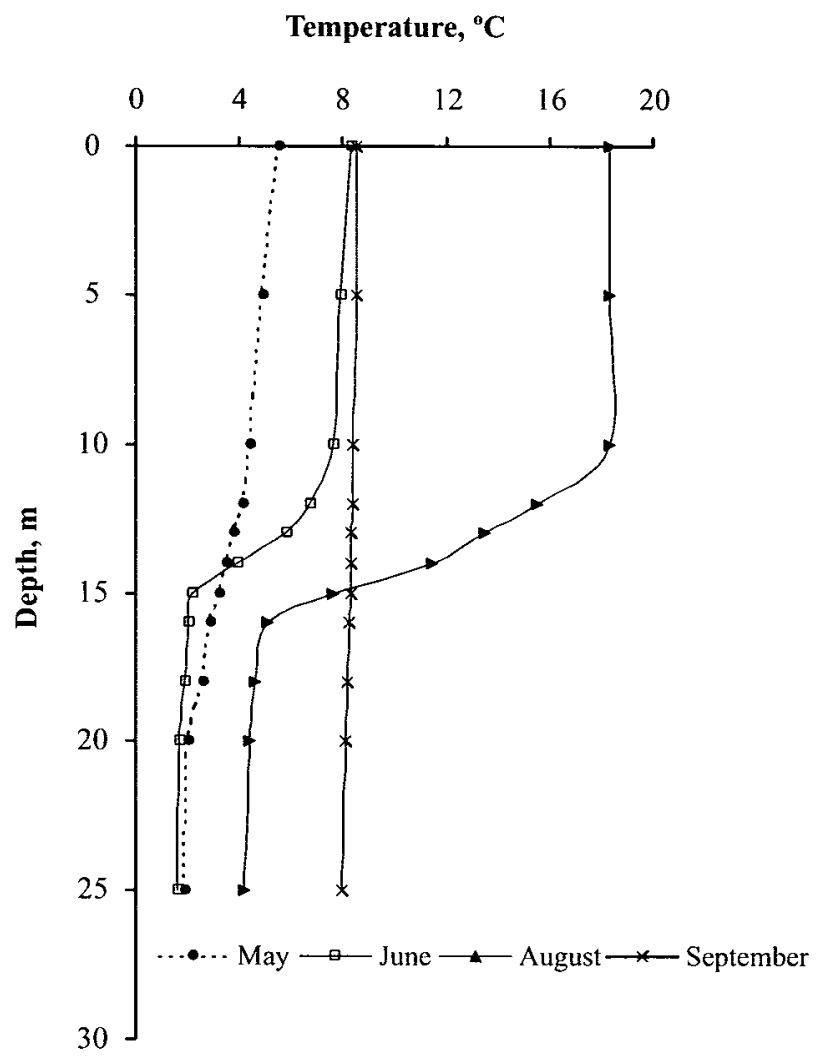

Fig. 3. Temperature profiles in the study area during different months.

Hence, the proportion of $N$. integer was small in the plankton samples during May. The species breed during summer (Kotta, 1976) and consequently the abundances of migrating $N$. integer gradually increased from May till September.

On the other hand Mysis spp. breed mainly during April-May (Simm \& Kotta, 1992). In June, when the share of juveniles was at its maximum, we observed high abundances of Mysis spp. in the water column. In August the peak of Mysis spp. migration was delayed about 3-4 hours as compared to June. It is likely that the difference is due to the higher share of large-sized Mysis specimens in the population that start their migration later in the evening.

Strong vertical mixing in September increased the deep water temperature so much that the cold-loving M. mixta and M. relicta retreated towards depths greater than $30 \mathrm{~m}$ (Kotta \& Kotta, 1999). Together with their occurrence in warm surface water in summer, this autumn migration indicates that the Mysis spp. need to retreat to cold water for at least some period of the day. This explains why only individuals of $N$. integer were found in the samples during September. 
Except the above-mentioned example, temperature did not affect significantly the vertical migration of mysids. According to Beeton (1960) M. relicta does not migrate through a pronounced thermocline with temperature gradients of around $2{ }^{\circ} \mathrm{C} \mathrm{m}^{-1}$. This was not the case in our study as we observed adult M. relicta in the surface water during August, although temperature gradients of $4{ }^{\circ} \mathrm{C} \mathrm{m}^{-1}$ were observed in the area. According to Chekhova (1961) high abundances of Mysis spp. are found close to the thermocline in the Gulf of Riga during night. However, our data demonstrated that both Mysis species, when they perform migrations, are often found in the surface layer. Our data also show that the vertical migrations of Mysis spp. are not restricted by temperatures higher than $12^{\circ} \mathrm{C}$ as postulated by Chekhova (1961).

\section{ACKNOWLEDGEMENTS}

This study was financed by the Estonian Governmental Programmes Nos. 0200792s98 and 0200797s98. We wish to thank Tiia Rosenberg and Verge Bogdanov for their help in the laboratory.

\section{REFERENCES}

Beeton, A. M. 1960. The vertical migration of Mysis relicta in Lakes Huron and Michigan. J. Fish. Res. Bd. Can., 17, 517-539.

Beeton, A. M. \& Bowers, J. A. 1982. Vertical migration of Mysis relicta Lovén. Hydrobiologia, 93, 53-61.

Chekhova, V. A. 1961. Vertical migration of Mysis mixta and M. oculata f. relicta in the Gulf of Riga. Tr. NIIRH SNH Latv. SSR, 3, 307-327 (in Russian).

Järvekülg, A. 1965. Eesti rannikuvete müsiididest. Eesti Loodus, 3, 145-151.

Kinne, O. 1955. Neomysis vulgaris Thompson, eine autökologisch-biologische Studie. Biol. Zentralbl., 74, 160-202.

Kotta, I. 1976. About breeding and the changes in the abundance and biomass of Neomysis vulgaris in Pärnu Bay. In Fishery Research in the Baltic Sea, Vol. 12, pp. 44-50. Zvaigzne, Riga (in Russian).

Kotta, I. 1980. The quantitative distribution and migrations of mysids in the Gulf of Riga. In Fishery Research in the Baltic Sea, Vol. 15, pp. 98-107. Zvaigzne, Riga (in Russian).

Kotta, I. 1984. Abundance, biomass and seasonal migration of Mysidacea in the Gulf of Riga. In Hydrobiological Regime of the Baltic Sea, pp. 92-101. IZB, Acad. Sci. Estonian SSR, Tallinn (in Russian).

Kotta, I. \& Kotta, J. 1999. Distribution and migration of mysids in the Gulf of Riga (Northern Baltic). Proc. Estonian Acad. Sci. Biol. Ecol., 48, 284-295.

Lassenby, D. C., Northcote, T. G. \& Fürst, M. 1986. Theory, practice, and effects of Mysis relicta introductions to North American and Scandinavian lakes. Can. J. Fish. Aquat. Sci., 43, $1277-1284$.

MacLaren, I. 1974. Demographic strategy of vertical migration by a marine copepod. Am. Nat., 108, 91-102.

Mägi, L. \& Lips, U. 1998. Budget components of water, salt, and nutrients in the Gulf of Riga in 1993-95. Proc. Estonian Acad. Sci. Biol. Ecol., 47, 14-31. 
Ojaveer, H. 1997. Composition and dynamics of fish stocks in the Gulf of Riga ecosystem. Diss. Biol. Univ. Tartuensis, 31, 1-138.

Rass, T. 1933. Guide for the Quantitative Sampling of Roe and Marine Larvae. GOIN, Moscow (in Russian).

Rudstam, L. G. \& Hansson, S. 1990. On the ecology of Mysis mixta (Crustacea, Mysidacea) in a coastal area of the northern Baltic proper. Ann. Zool. Fennici, 27, 259-263.

Rudstam, L. G., Danielsson, K., Hansson, S. \& Johansson, S. 1989. Diel vertical migration and feeding patterns of Mysis mixta (Crustacea, Mysidacea) in the Baltic Sea. Mar. Biol., 101, $43-52$.

Salemaa, H., Tyystjärvi-Muuronen, K. \& Aro, E. 1986. Life histories, distribution and abundance of Mysis mixta and Mysis relicta in the northern Baltic Sea. Ophelia, Suppl., 4, 239-247.

Sanina, L. V. 1961. About the biology of Neomysis vulgaris Thompson in the Gulf of Riga. Tr. NIIRH SNH Latv. SSR, 3, 293-306 (in Russian).

Simm, M. \& Kotta, I. 1992. The life cycle and production of Mysis mixta in the Gulf of Riga. In Taxonomy, Biology and Ecology of (Baltic) Mysids (Köhn, J., Jones, M. B. \& Moffat, A., eds.), pp. 45-54. Rostock University, Rostock.

\section{MÜSIIDIDE VERTIKAALSED RÄNDED LIIVI LAHES}

\section{Ilmar KOTTA ja Jonne KOTTA}

Mysis mixta, M. relicta ja Neomysis integer'i vertikaalseid rändeid uuriti Liivi lahe kirdeosas 1999. aasta maist septembrini. Kõigile kolmele müsiidiliigile olid omased ööpäevased ränded. Võrreldes kevade ja varasuvega olid ränded intensiivsemad hilissuvel ja sügisel. Noorte ja väikeste täiskasvanud isendite osakaal oli rännetes suur. Tavaliselt ilmus $N$. integer õhtuti esimesena veesambasse ning temale järgnesid Mysis'e liigid. Mõlemaid külmalembeseid Mysis'e liike leidus arvukalt pindmises veekihis vaatamata väga tugevate temperatuurigradientide esinemisele. 